\title{
The Distribution of Sodium-Potassium-Activated Adenosine Triphosphatase in Medulla and Cortex of the Kidney
}

\author{
Ernesto D. Hendler, Jorge Torretti, and Frankuin H. Epstein \\ From the Department of Internal Medicine, Yale University School of Medicine, \\ New Haven, Connecticut 06510
}

\begin{abstract}
A в S T RAC T The activity of sodium-potassium-activated adenosine triphosphatase (Na-K-ATPase) is considerably higher in homogenates of outer medulla than in the cortex or papilla of the kidney. The enzyme has similar kinetic characteristics in both cortex and medulla, and binds ouabain in the same proportion. The discrepancy in enzymatic activity is not paralleled by similar change in the activity of adenyl cyclase, 5'nucleotidase, glucose6-phosphatase, or succinic dehydrogenase. Na-K-ATPase is also higher in distal convoluted tubules (ventral slices) than in the proximal tubules (dorsal slices) of the kidney of Amphiuma. The high concentration of $\mathrm{Na}-\mathrm{K}$-ATPase in the red medulla of the kidney is probably related to the presence here of the thick ascending limb of the loop of Henle, and this has important implications with regard to the mechanism of sodium reabsorption by different portions of the nephron.
\end{abstract}

\section{INTRODUCTION}

There is mounting evidence that sodium-potassium-activated adenosine triphosphatase (Na-K-ATPase) ${ }^{1}$ plays an important role in the bulk reabsorption of sodium by the kidney (1) as well as in the reciprocal transfer of sodium and potassium across the plasma membrane of

This work was presented in part at the National Meeting of the American Society for Clinical Investigation; 4 May 1969 and at the 4th International Congress of Nephrology, Stockholm, Sweden, 23 June 1969.

Dr. Hendler is a Special Research Fellow of the U. S. Public Health Service (5-F3-AM-36,661) 1968-1970.

Dr. Torretti is a Visiting Scholar (Senior Fulbright-Hays Program) 1968-1971, and Fellow of the National Kidney Foundation 1968-1970. Dr. Torretti's permanent address is the University of Chile School of Medicine, Santiago, Chile.

Dr. Epstein is a Research Career Awardee of the U. S.

Public Health Service.

Received for publication 6 October 1970 and in revised form 18 January 1971.

${ }^{1}$ Abbreviations used in this paper: $K_{m}$, Michaelis constant; $\mathrm{Na}-\mathrm{K}$-ATPase, sodium-potassium-activated adenosine triphosphatase. intact cells (2). Because of the difference in function between different portions of the nephron, the distribution of Na-K-ATPase within the kidney is of special interest.

The present experiments indicate that the activity of $\mathrm{Na}-\mathrm{K}$-ATPase is considerably higher in the red, or outer, medulla than in the cortex of the kidney. This is probably related to the presence within the outer medulla of the thick ascending limb of Henle's loop. The difference is not paralleled by differences in other enzymes, including those thought to be bound to plasma membranes. The high concentration of Na-K-ATPase in distal portions of the nephron has important implications concerning the mechanism of sodium reabsorption by the kidney.

\section{METHODS}

The experimental animals used were as follows: mongrel dogs of either sex weighing 7.5-16.2 kg; male SpragueDawley rats of 200-350 g in weight, male albino guinea pigs weighing 200-300 g, and squirrel monkeys of 600-900 g. All these animals had free access to tap water and were fed the usual laboratory diet. The kidney of the urodele amphibian, Amphiuma, and of partridges, Alectoris barberi, were also studied.

Preparation of tissue. Under light ether or barbiturate anesthesia, kidneys were removed and chilled by placing them in ice cold $0.9 \%$ saline, or, in the case of Amphiuma, $100 \mathrm{~mm} \mathrm{NaCl}$ solution.

After removal of the capsule, a sagittal or transverse section of the kidney was done, and the cortex, red medulla, and white medulla were identified by examination with the naked eye. Tissue from each of these three zones was obtained by dissection with a scalpel on a glass dish placed over ice and covered with filter paper moistened with cold saline. Tissue adjacent to the boundaries between zones was discarded. In rats, when more than three enzymes were measured simultaneously, the kidneys of two or three animals were pooled. All the tissue fragments were blotted and weighed. The kidneys from Amphiuma ${ }^{2}$ were sliced parallel to the surface. Tissue from the ventral area, containing glomeruli and distal tubules, and from the dorsal area, con-

\footnotetext{
${ }^{2}$ Kindly supplied by Dr. Michael Wiederholt, Department of Physiology, Yale University School of Medicine.
} 
taining proximal tubules, were used and the intermediate area was discarded. Partridge kidneys ${ }^{3}$ were dissected submerged in cold saline, under a stereoscopic microscope. All medullary tissue is included in medullary cones, surrounded by a connective tissue sheath. This arrangement makes it easy to pick the medullary cones from the lacerated cortical tissue.

\section{Enzyme preparations}

Whole homogenate. The tissue was homogenized in a $20 / 1$ (v/w) solution containing $0.25 \mathrm{M}$ sucrose, $5 \mathrm{~mm} \mathrm{Na}$ EDTA, $30 \mathrm{~mm}$ imidazole, and $2.4 \mathrm{~mm}$ sodium deoxycholate (added immediately before use) at a $\mathrm{pH}$ 6.8. Homogenization was carried out in a glass homogenizer immersed in ice with a Teflon pestle at $1725 \mathrm{rpm}$ and $0.18 \mathrm{~mm}$ clearance, using 18-20 strokes. The homogenate was filtered through a double layer of gauze. Part of this suspension was used for the determination of enzyme activity in fresh whole homogenate and the remainder was used to prepare the total microsomal fraction.

Microsomal fraction. Whole homogenate suspension was centrifuged at $10,800 \mathrm{~g}$ in a refrigerated Sorvall centrifuge (Ivan Sorvall, Inc., Norwalk, Conn.) for $30 \mathrm{~min}$. The supernatant was carefully removed leaving a sufficient amount of fluid at the bottom to avoid contamination, and centrifuged at $105,000 \mathrm{~g}$ in a refrigerated Spinco ultracentrifuge (Beckman Instruments, Inc., Palo Alto, Calif.) for $60 \mathrm{~min}$. Supernatant was discarded and final sediment resuspended in $1.5-2.5 \mathrm{ml}$ of the original homogenizing solution without deoxycholate using a Vortex mixer (Scientific Industries, Inc., Queens Village, N. Y.). This suspension was kept frozen at $-20^{\circ} \mathrm{C}$ and assayed for enzyme activity within $24 \mathrm{hr}$.

$2200 \mathrm{~g}$ fraction. For the determination of adenyl cyclase, the tissue from cortex and red medulla of rat kidney was divided into two equal amounts. One was used to prepare whole homogenate as described above, and the remainder was homogenized with the same technique but in a $8 / 1$ (v/w) solution containing $50 \mathrm{~mm}$ Tris- $\mathrm{HCl}$ buffer at $\mathrm{pH} 7.4$. This suspension was centrifuged at $2200 \mathrm{~g}$ in a refrigerated Sorvall centrifuge for $10 \mathrm{~min}$. The supernatant was discarded and the sediment was resuspended in the same buffer. This suspension was centrifuged again in the same way and the final sediment resuspended in half the original volume of $50 \mathrm{~mm}$ Tris- $\mathrm{HCl}$ buffer containing in addition $10 \mathrm{~mm}$ theophylline, $10 \mathrm{~mm}$ magnesium chloride, $10 \mathrm{~mm}$ sodium

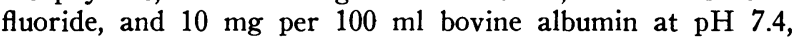
and assayed immediately for adenyl cyclase activity.

\section{Enzyme assays}

Na-K-ATPase, Mg-ATPase, and glucose-6-phosphatase were determined by methods previously reported by our laboratory (3) with minor modifications. Whole homogenate samples were assayed $45 \mathrm{~min}$ after homogenization and total microsomal fraction within $24 \mathrm{hr}$. Total ATPase activity was determined in $5 \mathrm{ml}$ of a reaction mixture prewarmed at $37^{\circ} \mathrm{C}$, of the following composition: $\mathrm{NaCl} 100$ $\mathrm{mm}$; $\mathrm{KCl} 20 \mathrm{~mm}$; imidazole buffer $10 \mathrm{~mm}$; and $6 \mathrm{~mm}$ each $\mathrm{MgCl}_{2}$ and disodium adenosine triphosphate (ATP,

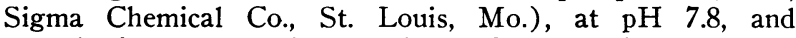
enough tissue suspension to give a final protein concentration of $0.04-0.08 \mathrm{mg} / \mathrm{ml}$ for whole homogenates and $0.01-$ $0.05 \mathrm{mg} / \mathrm{ml}$ for microsomal suspensions. The reaction was

\footnotetext{
${ }^{3}$ Samples were kindly supplied by Dr. Thomas L. Poulson, Department of Biology, Yale University.
}

started by the addition of $\mathrm{MgCl}_{2}$ and $\mathrm{ATP}$, carried out for $15 \mathrm{~min}$ at $37^{\circ} \mathrm{C}$ in a shaking water bath, and terminated by the addition of $1 \mathrm{ml}$ ice cold $35 \%$ (w/v) trichloracetic acid. After centrifugation, inorganic phosphate was determined in the supernatant by the method of Fiske and Subbarow (4), the optical density being read at $660 \mathrm{~m} \mu$ in a Gilford spectrophotometer (Gilford Instrument Company, Oberlin, Ohio). The $\mathrm{Na}^{+}-\mathrm{K}^{+}$-stimulated portion of the ATPase was defined as the difference between the inorganic phosphate liberated in the presence and in the absence of potassium. Correction was made for the spontaneous, nonenzymatic breakdown of ATP, measured as inorganic phosphate liberated under the same experimental conditions in the absence of enzyme, which usually accounted for less than $15 \%$ of the total inorganic phosphate present.

The protein content of tissue suspensions was determined by the method of Lowry, Rosebrough, Farr, and Randall (5), using crystalline bovine albumin dissolved in homogenizing solution as a standard. The ATPase activity is expressed in micromoles of inorganic phosphate released per milligram of protein per hour.

Succinic dehydrogenase was determined by measuring the reduction of ferricyanide in the presence of succinate, according to the method of Bonner (6). The activity is expressed in arbitrary units of $\Delta$ optical density reading per milligram of protein per hour. 5'-Nucleotidase was measured as described by Michell and Hawthorne (7). Whole homogenate samples were assayed $5 \mathrm{~min}$ after homogenization, pipetting $0.1 \mathrm{ml}$ of the suspension in $2 \mathrm{ml}$ of a solution containing $100 \mathrm{~mm} \mathrm{KCl}, 10 \mathrm{~mm} \mathrm{MgCl}, 10 \mathrm{~mm} \mathrm{~K}-\mathrm{Na}$ tartrate, and $50 \mathrm{~mm}$ Tris at $\mathrm{pH}$ 7.4. The mixture was prewarmed at $37^{\circ} \mathrm{C}$ and the reaction started by the addition of $0.1 \mathrm{ml}$ of $100 \mathrm{~mm} 5^{\prime}$ adenosine monophosphate. After $45 \mathrm{~min}$ incubation at $37^{\circ} \mathrm{C}$ in a Dubnoff metabolic shaker the reaction was terminated by the addition of 1 $\mathrm{ml}$ ice-cold $25 \%(\mathrm{w} / \mathrm{v})$ trichloroacetic acid. The precipitated protein was discarded after centrifugation and inorganic phosphate determined as described for the ATPases. The activity of the enzyme was also expressed as micromoles of inorganic phosphate liberated per milligram of protein per hr.

Adenyl cyclase activity was determined in a membrane preparation from homogenates of rat kidney fully stimulated in vitro with sodium fluoride. The conversion of $\left({ }^{3} \mathrm{H}\right)$ adenosine triphosphate (Schwarz Bio Research Inc., Orangeburg, N. Y.) to $\left({ }^{3} \mathrm{H}\right)$-cyclic $3^{\prime} 5^{\prime}$-adenosine monophosphate $\left(\left({ }^{8} \mathrm{H}\right)\right.$-cyclic AMP) was measured in an assay similar to that described by Krishna, Weiss, and Brodie (8) and Chase and Aurbach for kidney homogenates (9). The $2200 \mathrm{~g}$ particulate fraction was prepared as described above with a final protein concentration of $4-7 \mathrm{mg} / \mathrm{ml}$. The incubation medium for the assay of adenyl cyclase contained Tris- $\mathrm{HCl}$ buffer $50 \mathrm{~mm}$, theophylline $10 \mathrm{~mm}, \mathrm{MgCl}$ $10 \mathrm{~mm}$, NaF $10 \mathrm{~mm}$, bovine albumin $10 \mathrm{mg}$ per. $100 \mathrm{ml}$ $\left({ }^{3} \mathrm{H}\right)$-ATP $4 \mathrm{~mm}$ (specific activity $9 \mathrm{mCi} / \mathrm{mmole}$ ), and enzyme preparation (equivalent to $1.5-3.0 \mathrm{mg}$ of protein) in a final volume of $0.6 \mathrm{ml}$. The reaction was started by the addition of $\left({ }^{8} \mathrm{H}\right)$-ATP and incubated at $37^{\circ} \mathrm{C}$ for $4 \mathrm{~min}$. It was terminated after adding $0.1 \mathrm{ml}$ of a $5 \mathrm{mg} / \mathrm{ml}$ solution of carrier cyclic AMP, by immersion in a boiling water bath for $3 \mathrm{~min}$. The tubes were centrifuged and the supernatant was applied to a 0.5 by $3 \mathrm{~cm}$ column of Dowex 50 W-X 8, 100-200 mesh in the hydrogen form (Bio-Rad Laboratories, Richmond, Calif.) prepared by pipetting a $50 \%(\mathrm{v} / \mathrm{v})$ suspension of the resin in $50 \mathrm{~mm}$ Tris $\mathrm{HCl}$ into columns and washing them with water. After elution 
with water, cyclic AMP appearing in the 5th-7th $\mathrm{ml}$ of effluent was measured. To this portion of the effluent, 0.3 $\mathrm{ml}$ each of $0.25 \mathrm{M} \mathrm{ZnSO}$ and $0.25 \mathrm{M} \mathrm{Ba}(\mathrm{OH})_{2}$ solutions were added, mixed, and centrifuged. The supernatant was transferred to another tube by decantation and the $\mathrm{Zn}-\mathrm{Ba}$ precipitation repeated. The recovery of cyclic $3^{\prime} 5^{\prime}-\mathrm{AMP}$ in these fractions from the column was $30-35 \%$ as measured by absorption at $260 \mathrm{~m} \mu$ in a Zeiss spectrophotometer or in a parallel experiment using $\left({ }^{3} \mathrm{H}\right)$-cyclic $3^{\prime} 5^{\prime}$-AMP. 0.5 $\mathrm{ml}$ of the final supernatant was added to $15 \mathrm{ml}$ of Bray's (10) solution and ${ }^{3} \mathrm{H}$ was measured in a Packard Tri-Carb liquid scintillation spectrometer (Packard Instrument Co., Downers Grove, Ill.). Appropriate corrections were made in the calculations for $100 \%$ recovery. The amount of cyclic 3'5'-AMP generated was calculated from the specific activity of the substrate, $\left({ }^{8} \mathrm{H}\right)-\mathrm{ATP}$. Activity was expressed as picomoles of cyclic $3^{\prime} 5^{\prime}$-AMP formed per milligram of protein per $4 \mathrm{~min}$. Protein content of the tissue suspensions was determined by the method of Lowry et at (5).

Ouabain binding. Guinea pig or dog kidney microsomes prepared as described above from cortex and medulla, were incubated in stainless steel centrifuge tubes with a reaction mixture containing $2 \mathrm{~mm}$ ATP, $5 \mathrm{~mm} \mathrm{MgCl}, 1 \mathrm{~mm}$ EDTA, $100 \mathrm{~mm} \mathrm{NaCl}$, and $50 \mathrm{~mm}$ Tris $\mathrm{HCl} .\left({ }^{3} \mathrm{H}\right.$ )-ouabain (specific activity $1.5 \mathrm{mCi} / \mu$ mole) was used at a final concentration of $3 \times 10^{-7} \mathrm{M}$. The reaction was started by the addition of $0.2 \mathrm{ml}$ of the microsomal suspension (containing $0.2-$ $0.9 \mathrm{mg}$ of protein). After $3 \mathrm{~min}$ of incubation at $37^{\circ} \mathrm{C}$ in a Dubnoff metabolic shaker, the procedure of Matsui and Schwartz (11) was followed, counting the radioactivity bound to the microsome pellet in a Packard tricarb liquid scintillation spectrometer. The binding of $\left({ }^{8} \mathrm{H}\right)$-ouabain was expressed as picomoles of ouabain per micromole of $\mathrm{Pi}$ liberated by the same preparation when its $\mathrm{Na}-\mathrm{K}$-ATPase activity was measured.

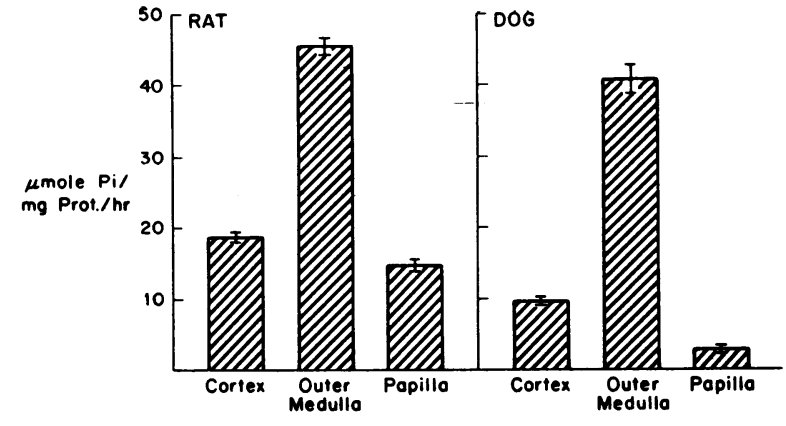

Figure 1 Distribution of Na-K-ATPase in whole homogenates of rat and dog kidney. Bars represent mean activity $\pm \mathrm{SE}$.

Expression of results. Mean values $\pm \mathrm{SE}$ are given. Significance of differences between means were calculated by Student's $t$ test.

\section{RESULTS}

Distribution of Na-K-ATPase within the kidney (Fig. 1, Tables $I$ and $I I)$. The specific activity of Na-KATPase in whole homogenates of red medulla from rat kidney was $45.5 \pm 1.2 \mu$ moles $\mathrm{Pi} / \mathrm{mg}$ protein per hour. This is $2 \frac{1}{2}$ times that of the cortex $(18.8 \pm 0.6)$ and 3 times that of the white medulla $(14.7 \pm 0.8)$. The specific activity of total microsomes (membrane fragments sedimenting between 10,800 and $105,000 \mathrm{~g}$ ) derived from red medulla of rat kidney was $115.0 \pm 8.4,1 \frac{1}{2}$ times that

TABLE I

Distribution of Na-K-ATPase and Other Enzymes within the Kidney of the Rat*

\begin{tabular}{|c|c|c|c|c|}
\hline Enzyme & Fraction & Cortex & Red medulla & White medulla \\
\hline Na-K-ATPase, $\mu$ moles $P i / m g$ protein per $h r$. & $\begin{array}{l}\text { Whole homogenate } \\
\text { Total microsomes }\end{array}$ & $\begin{array}{c}18.8 \pm 0.6 \\
(\mathrm{n}=18) \\
75.1 \pm 5.37 \\
(\mathrm{n}=8)\end{array}$ & $\begin{array}{c}45.5 \pm 1.2 \\
(\mathrm{n}=17) \\
115.0 \pm 8.4 \\
(\mathrm{n}=8)\end{array}$ & $\begin{aligned} 14.7 & \pm 0.8 \\
(\mathrm{n} & =4) \\
27.6 & \pm 3.6 \\
(\mathrm{n} & =3)\end{aligned}$ \\
\hline Mg-ATPase, $\mu$ moles $P i / m g$ protein per $h r$ & $\begin{array}{l}\text { Whole homogenate } \\
\text { Total microsomes }\end{array}$ & $\begin{array}{c}36.5 \pm 0.9 \\
(\mathrm{n}=18) \\
51.9 \pm 1.5 \\
(\mathrm{n}=6)\end{array}$ & $\begin{array}{c}41.1 \pm 1.2 \\
(\mathrm{n}=17) \\
48.3 \pm 2.3 \\
(\mathrm{n}=6)\end{array}$ & $\begin{array}{c}28.9 \quad \pm 0.9 \\
\quad(\mathrm{n}=4) \\
53.6 \quad \pm 14.9 \\
\quad(\mathrm{n}=3)\end{array}$ \\
\hline $\begin{array}{l}\text { Adenyl cyclase } \mu m o l e s 3^{\prime} 5^{\prime} A M P / m g \text { protein } \\
\quad \text { per } h r\end{array}$ & $2200 \mathrm{~g}$ fraction & $\begin{array}{c}465 \quad \pm 29 \\
(n=.18)\end{array}$ & $\begin{array}{r}627 \pm 52 \\
(\mathrm{n}=17)\end{array}$ & \\
\hline $5^{\prime}$ nucleotidase $\mu$ moles $P i / m g$ protein per $h r$ & Whole homogenate & $\begin{array}{l}5.39 \pm 0.17 \\
(\mathrm{n}=14)\end{array}$ & $\begin{array}{l}2.50 \pm 0.11 \\
(\mathrm{n}=14)\end{array}$ & $\begin{array}{l}0.65 \pm 0.02 \\
(n=3)\end{array}$ \\
\hline $\begin{array}{l}\text { Glucose-6-phosphatase } \mu \text { moles } P i / m g \text { protein } \\
\quad \text { per } h r\end{array}$ & Total microsomes & $\begin{array}{c}56.0 \pm 6.2 \\
(\mathrm{n}=4)\end{array}$ & $\begin{array}{l}6.4 \pm 0.5 \\
(\mathrm{n}=4)\end{array}$ & \\
\hline Succinic dehydrogenase $U / m g$ protein per $h r$ & Whole homogenate & $\begin{array}{l}1.64 \pm 0.12 \\
(\mathrm{n}=3)\end{array}$ & $\begin{array}{l}1.23 \pm 0.05 \\
(\mathrm{n}=3)\end{array}$ & $\begin{aligned} & 0.26 \pm 0.05 \\
&(\mathrm{n}=3)\end{aligned}$ \\
\hline
\end{tabular}

* Values given are mean \pm SE. $\mathrm{n}$ in this and subsequent tables refers to number of separate animals or pools of animals on which an observation was made. 
TABLE II

Distribution of Na-K-ATPase and other Enzymes within the Kidney of the Dog*

\begin{tabular}{|c|c|c|c|c|}
\hline Enzyme & Fraction & Cortex & Red medulla & White medulla \\
\hline Na-K-ATPase, $\mu$ moles $P i / m g$ protein per $h r$ & $\begin{array}{l}\text { Whole homogenate } \\
\text { Total microsomes }\end{array}$ & $\begin{array}{c}9.7 \pm 0.6 \\
(\mathrm{n}=8) \\
43.4 \pm 4.6 \\
(\mathrm{n}=6)\end{array}$ & $\begin{array}{c}40.8 \pm 2.1 \\
(n=8) \\
221.8 \pm 19.2 \\
(n=6)\end{array}$ & $\begin{array}{c}2.94 \pm 0.5 \\
(\mathrm{n}=7) \\
15.3 \pm 1.8 \\
(\mathrm{n}=6)\end{array}$ \\
\hline Mg-ATPase $\mu$ moles $P i / m g$ protein per $h r$ & $\begin{array}{l}\text { Whole homogenate } \\
\text { Total microsomes }\end{array}$ & $\begin{array}{c}37.5 \pm 1.6 \\
(\mathrm{n}=8) \\
54.9 \pm 4.4 \\
(\mathrm{n}=6)\end{array}$ & $\begin{array}{c}49.5 \pm 2.8 \\
(\mathrm{n}=8) \\
73.9 \pm 5.0 \\
(\mathrm{n}=6)\end{array}$ & $\begin{array}{c}34.3 \quad \pm 2.2 \\
(\mathrm{n}=7) \\
97.5 \pm 10.9 \\
(\mathrm{n}=6)\end{array}$ \\
\hline 5'nucelotidase $\mu$ moles $P i / m g$ protein per $h r$ & Whole homogenate & $\begin{array}{c}0.60 \pm 0.06 \\
(n=8)\end{array}$ & $\begin{array}{c}0.26 \pm 0.03 \\
(n=8)\end{array}$ & $\begin{array}{c}0.35 \pm 0.03 \\
(n=7)\end{array}$ \\
\hline Glucose-6-phosphatase $\mu$ moles $P i / m g$ protein per $h r$ & Total microsomes & $\begin{array}{c}58.6 \pm 7.4 \\
(n=6)\end{array}$ & $\begin{array}{c}9.2 \pm 0.9 \\
(n=6)\end{array}$ & $\begin{array}{r}6.6 \pm 0.7 \\
(n=6)\end{array}$ \\
\hline Succinic dehydrogenase $U / m g$ protein per $h r$ & Whole homogenate & $\begin{array}{c}1.60 \pm 0.07 \\
(\mathrm{n}=6)\end{array}$ & $\begin{array}{c}0.90 \pm 0.04 \\
(n=6)\end{array}$ & $\begin{array}{c}0.20 \pm 0.02 \\
(n=6)\end{array}$ \\
\hline
\end{tabular}

*Values given are mean $\pm \mathrm{SE}$.

of cortical microsomes and more than 4 times the specific activity of microsomes derived from white medulla.

The discrepancy in Na-K-ATPase distribution within the kidney is even greater in the dog than in the rat. The specific activity of the enzyme in whole homogenates of outer medulla is 4 times higher than in the cortex ( $40.8 \pm 2.1$ in red medulla versus $9.7 \pm 0.6$ in cortex). The activity in the total "microsomal" fraction of dog red medulla is $\mathbf{5}$ times higher than in cortical microsomes.

Distribution of Na-K-ATPase in the kidneys of other species (Table III). The Na-K-ATPase activity in red medulla appears to be higher than in the cortex in the

TABLE III

Na-K-ATPase Specific Activity in Cortex and Outer Medulla in the Kidney of Different Species

\begin{tabular}{|c|c|c|c|c|}
\hline \multirow{3}{*}{$\frac{\text { Specie }}{\text { Guinea pig* }}$} & \multirow{3}{*}{$\begin{array}{c}\text { Preparation } \\
\text { Whole homogenate }\end{array}$} & \multirow{3}{*}{$\frac{n}{4}$} & \multicolumn{2}{|c|}{ Na-K-ATPase } \\
\hline & & & Cortex & $\begin{array}{c}\text { Red } \\
\text { medulla }\end{array}$ \\
\hline & & & $11.7 \pm 0.46$ & $33.5 \pm 1.41$ \\
\hline Guinea pig* & Total microsomes & 16 & $23.0 \pm 0.79$ & $52.2 \pm 2.13$ \\
\hline Monkey* & Whole homogenate & 3 & $11.4 \pm 1.33$ & $29.9 \pm 1.27$ \\
\hline Partridge* & Whole homogenate & 4 & $10.4 \pm 0.61$ & $18.1 \pm 1.34$ \\
\hline Catf & Total microsomes & & 0.22 & 0.44 \\
\hline Rabbit $\delta$ & Total microsomes & 7 & $5.01 \pm 0.69$ & $9.84 \pm 1.08$ \\
\hline
\end{tabular}

* Specific activity is expressed in micromoles $\mathrm{Pi}$ /milligrams protein per $\mathrm{hr}$. Values are mean $\mathrm{SE}$.

$\ddagger$ From Bonting et al. (12). Specific activity is expressed in micromoles $\mathrm{Pi} /$ grams wet tissue per $\mathrm{hr}$.

8 From Beyth and Gutman (13). Specific activity is expressed in micromoles $\mathrm{Pi} /$ milligrams protein per $\mathrm{hr}$. kidneys of most vertebrates. In addition to rat and dog we studied two other mammals, the guinea pig and the squirrel monkey. In these species enzymatic activity in the red medulla was almost 3 times that in cortex. Similar results were obtained for the cat by Bonting, Simon, and Hawkins (12) and for the rabbit by Beyth and Gutman (13). In one bird studied, the barberi partridge, the activity of enzyme in red medulla also exceeded that in the cortex. These results are interesting, since birds share with mammals the presence of a loop of Henle. In whole homogenates of kidneys from guinea pig, monkey, dog, and partridge, Mg-ATPase activity is slightly higher in the outer medulla, but the difference is not nearly so great as that of the ouabain-sensitive enzyme.

$N a-K-A T P a s e$ distribution in the kidney of the urodele amphibian, Amphiuma (Table IV, Figs. 2, and 3). The predominant structure in the red outer medulla of rats and presumably other animals is the thick ascending limb of Henle's loop, whereas the cortex is chiefly, though not exclusively, made up of proximal convoluted tubules $(14,15)$. The foregoing results, therefore, suggest that the activity of Na-K-ATPase might be much higher in distal portions of the nephron than in the proximal tubule, a speculation supported by recent direct measurements by Schmidt and Dubach (16). The kidney of the urodele amphibian, Amphiuma, because of its peculiar configuration offers an interesting opportunity to clarify this idea. In the Amphiuma kidney (Fig. 2), the distal tubules are all on the ventral surface, where they lie interspersed with glomeruli; the dorsal half of the kidney is composed entirely of proximal tu- 
TABLE IV

Distribution of Na-K-ATPase and Other Enzymes within the Kidney of Amphiuma*

\begin{tabular}{|c|c|c|c|c|c|}
\hline & $\frac{\text { Na-K-ATPase }}{\text { Whole homogenate }}$ & $\frac{\text { Mg-ATPase }}{\text { Whole homogenate }}$ & $\frac{5^{\prime} \text { Nucleotidase }}{\text { Whole homogenate }}$ & $\begin{array}{c}\text { Glucose-6- } \\
\text { Phosphatase } \\
\text { Total microsomes }\end{array}$ & $\begin{array}{l}\text { Succinic dehydro- } \\
\frac{\text { genase }}{\text { Whole homogenate }}\end{array}$ \\
\hline & \multicolumn{2}{|c|}{ umoles $\mathrm{Pi} / \mathrm{mg}$ protein per $\mathrm{hr}$} & \multicolumn{2}{|c|}{ umoles $P i / m g$ protein per $h r$} & $U / m g$ prolein per $h r$ \\
\hline Dorsal (proximal tubules) & $\begin{array}{c}1.93 \pm 0.24 \\
(n=6)\end{array}$ & $\begin{array}{c}18.05 \pm 1.58 \\
(n-6)\end{array}$ & $\begin{array}{c}0.54 \pm 0.13 \\
(\mathrm{n}=4)\end{array}$ & $\begin{array}{c}5.80 \\
(\mathrm{n}=2)\end{array}$ & $\begin{array}{c}0.32 \pm 0.04 \\
(\mathrm{n}=4)\end{array}$ \\
\hline Ventral (distal tubules) & $\begin{array}{c}8.76 \pm 1.01 \\
(n=6)\end{array}$ & $\begin{array}{c}28.08 \pm 2.23 \\
(n=6)\end{array}$ & $\begin{array}{c}0.66 \pm 0.02 \\
(n=4)\end{array}$ & $\begin{array}{c}4.33 \\
(n=2)\end{array}$ & $\begin{array}{c}0.39 \pm 0.03 \\
(n=4)\end{array}$ \\
\hline
\end{tabular}

*Values given are mean $\pm \mathrm{sE}$.

bules (17). The activity of Na-K-ATPase was 4.5 times higher in slices of the ventral surface, containing distal tubules, than in those of the dorsal surface, containing proximal tubules. Neither 5 '-nucleotidase, glucose-6phosphatase, nor succinic dehydrogenase paralleled this distribution, their specific activity in the ventral slices being the same or even lower than that in dorsal slices. $\mathrm{Mg}$-ATPase was $56 \%$ higher in the ventral portion of the kidney than in dorsal, the difference being much less spectacular than for Na-K-ATPase (Fig. 3).

Kinetic studies (Table V, Figs. 4 and 5). To ascertain if the kinetic characteristics of Na-K-ATPase prepared from red medulla were the same as or different from those of the cortical enzyme, $K_{m}$ values were measured, considering both MgATP and $\mathrm{Na}^{+}$as substrates. These determinations were made on the microsomal fractions from rat and dog kidney homogenates, using the method of Lineweaver and Burk. The $K_{m}$ for MgATP and $\mathrm{Na}^{+}$were almost identical within each species in enzyme preparations from cortex and red medulla. The $K_{m}$ for MgATP was about $1 \mathrm{~mm}$ in both $\operatorname{dog}$ and rat microsomes. $K_{m}$ for $\mathrm{Na}^{+}$was 22 and $27 \mathrm{~mm}$ in rat and dog respectively. These experiments indicate that although the specific activity of medullary Na-K-ATPase

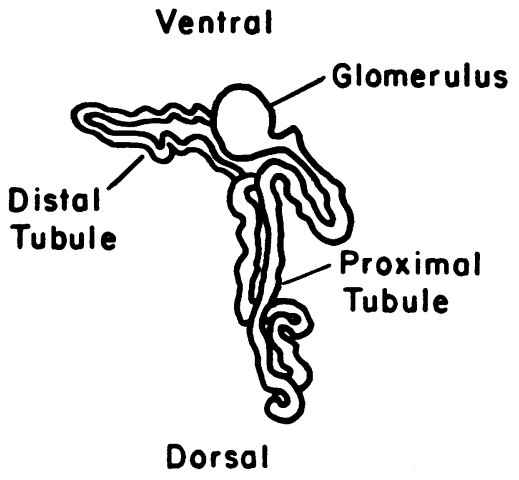

Figure 2 Tracing of an Amphiuma nephron (after W. J. Sullivan) (17). is higher than that of the cortical enzyme preparation, their kinetic characteristics are similar.

Binding of $\left({ }^{s} H\right.$ )ouabain (Table VI). Despite the dissimilar levels of $\mathrm{Na}-\mathrm{K}$-ATPase activity in microsomes prepared from guinea pig kidney, cortex, or medulla, the binding of ouabain in vitro by these membrane fragments was directly proportional to the specific activity of Na-K-ATPase. Thus, the quantity of ouabain bound per unit of enzyme activity was almost identical for both cortex and medulla, at about $1.3 \times 10^{-12}$ moles ouabain/ micromole $\mathrm{Pi}$ per hr. In the kidney of one dog studied this ratio was $1.25 \times 10^{-12}$ in the cortex and $0.95 \times 10^{-12}$ in the medulla.

Distribution of other enzymes within the kidney (Tables $I$ and II, Fig. 6). The higher activity of Na-KATPase in the red medulla versus the cortex of the kidney was not paralleled by a similar distribution of the other enzymes tested. 5'-nucleotidase, an enzyme said to be localized in the plasma membrane (18), was significantly lower in the red medulla than in the cortex, both in the rat and in the dog. Adenyl cyclase, also thought to be situated in the plasma membrane (19), was somewhat higher in the outer medulla of the rat kidney than in the cortex, but the difference was not so

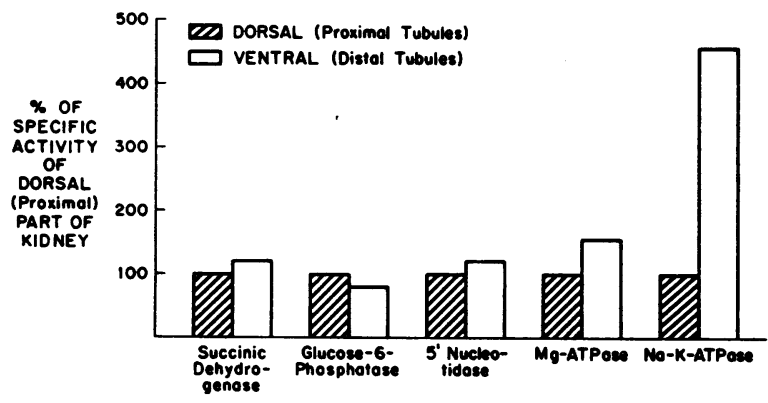

Figure 3 Distribution of enzymes in whole homogenates of Amphiuma kidney. The cross-hatched bars represent the specific activity in the dorsal part (proximal tubules) of the kidney expressed as $100 \%$. The open bars represent the specific activity in ventral slices (distal tubules) expressed as a percentage of that in the dorsal portion.

Na-K-ATPase in Renal Cortex and Medulla 
TABLE V

Kinetic Characteristics of Na-K-ATPase in Microsomes of Cortex and Outer Medulla

\begin{tabular}{ccc}
\hline & $K_{\mathrm{m}}(\mathrm{Mg}$ ATP $)$ & $K_{\mathrm{m}}\left(\mathrm{Na}^{+}\right)$ \\
\hline Rat & $(\mathrm{n}=5)$ & $(\mathrm{n}=2)$ \\
Cortex & $1.04 \pm 0.07 \mathrm{mM}$ & $22.8 \mathrm{mM}$ \\
Medulla & $1.02 \pm 0.08 \mathrm{mM}$ & $22.0 \mathrm{mM}$ \\
& $(\mathrm{n}=2)$ & $(\mathrm{n}=2)$ \\
Dog & & \\
Cortex & $0.85 \mathrm{mM}$ & $27.4 \mathrm{mM}$ \\
Medulla & $0.91 \mathrm{mM}$ & $26.3 \mathrm{mM}$ \\
\hline
\end{tabular}

great as that for Na-K-ATPase. Succinic dehydrogenase, a mitochondrial enzyme, and glucose-6-phosphatase, a microsomal enzyme associated with gluconeogenesis, were both lower in the red medulla than in the cortex, in the rat as well as in the dog. The activity of the residual, $\mathrm{Mg}$-stimulated ATPase in total microsomes from rat and dog, was the same or only slightly higher in outer medulla as compared to the cortex.

\section{DISCUSSION}

It was pointed out by Bonting and his coworkers that the distribution of Na-K-ATPase within the kidney is not uniform, longitudinal slices through the center of the kidney containing more enzyme than the outer ones containing only cortex (12). Subsequent reports have confirmed a difference in Na-K-ATPase activity between medulla and cortex $(13,20-25)$. The discrepancy has not been clearly defined nor has its significance been fully explored. As illustrated in the present experiments, the specific activity of Na-K-ATPase is considerably higher in the red (outer) medulla than in the cortex or white medulla. The enzyme preparations derived from both regions of the kidney appear to be similar in that their $K_{m}$ for MgATP is almost identical, as is the $K_{m}$ for sodium. In addition, the capacity of the enzyme to bind ouabain in vitro is exactly the same in preparations derived from both cortex and medulla suggesting that the high activity in medulla is due to a higher concentration of enzyme molecules rather than to other factors like the presence of enhancing or the absence of inhibitory materials. It seems likely that although the activity of Na-K-ATPase is higher in the medulla than in the cortex, the enzyme involved is the same, rather than a different one.

The discrepancy in the distribution of the enzyme is emphasized by the fact that it is not paralleled by any of the other enzymes measured. These included 5'-nucleotidase and adenyl cyclase, both thought to be bound to the plasma membrane; glucose-6-phosphatase, a microsomal enzyme; succinic dehydrogenase, a mitochon- drial enzyme; and Mg-ATPase. Thus the high medullary activity of Na-K-ATPase is not part of a general increase in enzymatic activity in this portion of the kidney. Because adenyl cyclase and 5 -nucleotidase activities are not elevated in the outer medulla, it seems improbable that a simple increase in the quantity of plasma membrane material in cells of this region is responsible for the high activity of $\mathrm{Na}-\mathrm{K}$-ATPase.

The microscopic anatomy of the various portions of the kidney has been most carefully studied in the rat (14). In this species the predominant structure in the outer medulla (indeed, the one that defines this region) is the thick ascending limb of Henle's loop, characterized by many mitochondria and a proliferation of basal infoldings of the periluminal plasma membrane $(26,27)$. The cortex, on the other hand, is largely made up of proximal convoluted tubules $(26,27)$, within which are interspersed the fewer and less bulky distal convolutions.

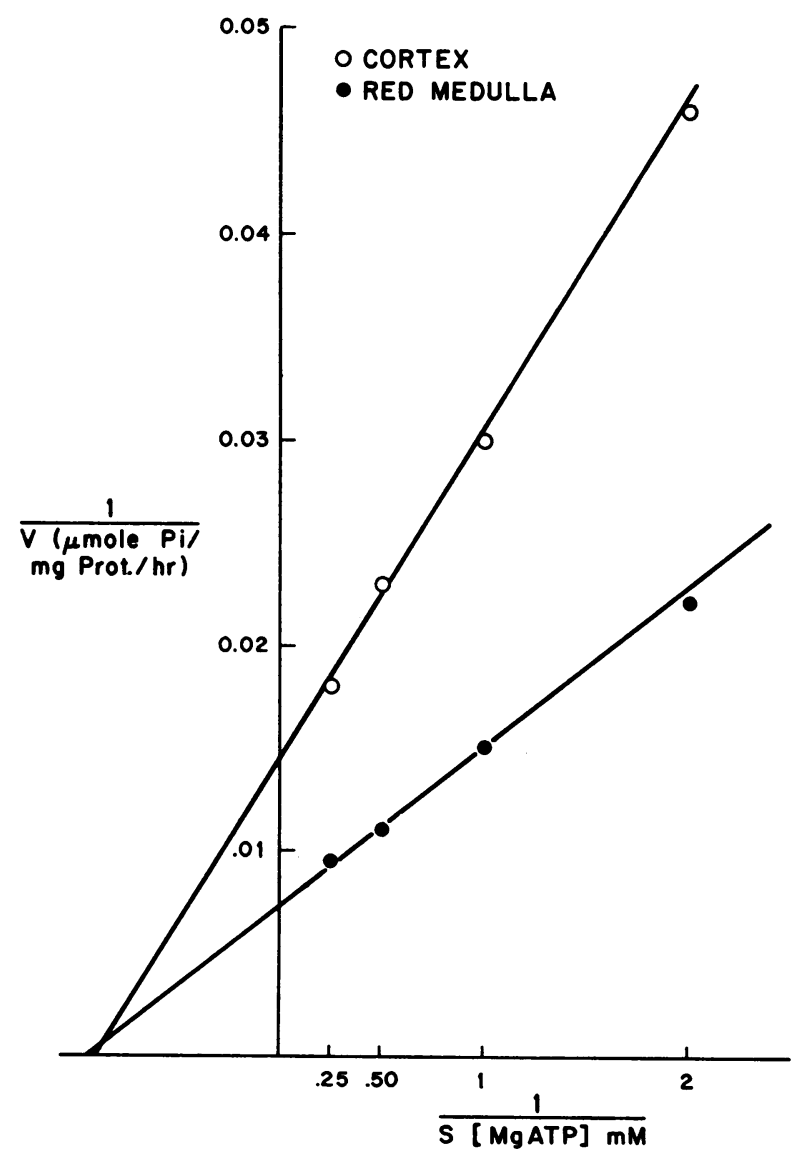

Figure $4 K_{m}$ for MgATP of microsomal Na-K-ATPase in cortex and medulla of rat kidney. Rate of $\mathrm{Pi}$ release as a function of $\mathrm{MgATP}$ concentration plotted according to the method of Lineweaver and Burk. Each point represents the mean of five determinations in microsomes of rat kidney. $\bigcirc$ Cortex; $\bullet$ Red medulla. 


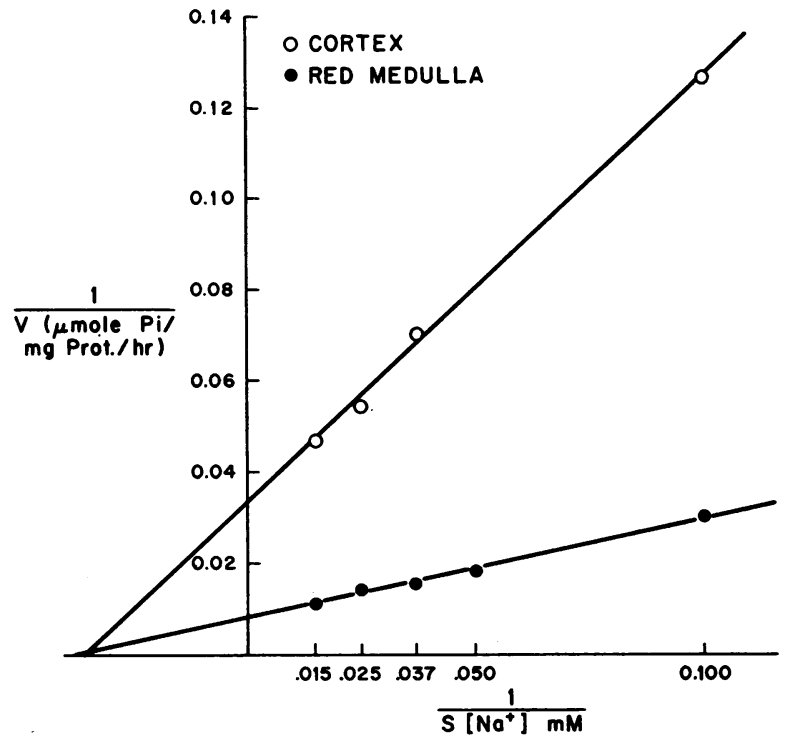

Figure $5 K_{m}$ for $\mathrm{Na}^{+}$of microsomal Na-K-ATPase in cortex and medulla of dog kidney. Rate of $\mathrm{Pi}$ release as a function of $\mathrm{Na}^{+}$concentration plotted as in Fig. 2. Each point represents the mean of duplicate determinations. Cortex; Red medulla.

The inner, or white, medulla is composed of thin limbs of the loop of Henle and collecting ducts. It would appear, then, that the activity of Na-K-ATPase is especially high in cells lining the thick ascending limb of the loop of Henle.

The idea that distal segments of the nephron are chiefly responsible for the high activity in outer medulla is supported by the results in the urodele amphibian, Amphiuma. In this species, where relatively pure homogenates of "distal" and "proximal" tubules can be obtained easily, homogenates of "distal" tubules contained
TABLE VI

Binding of $\left({ }^{3} \mathrm{H}\right)$-Ouabain to Kidney Microsomes

\begin{tabular}{|c|c|c|c|}
\hline & $\mathrm{n}$ & Na-K-ATPase & $\begin{array}{c}\text { Ouabain binding/ } \\
\text { Na-K-ATPase }\end{array}$ \\
\hline & & $\begin{array}{l}\text { umole } P i / m g \\
\text { protein per } \mathrm{hr}\end{array}$ & $\begin{array}{l}\text { Pmole ouabain/ } \\
\text { } 4 \text { mole } P i\end{array}$ \\
\hline \multicolumn{4}{|l|}{ Guinea pig } \\
\hline Cortex & 12 & $23.5 \pm 0.97$ & $1.29 \pm 0.07$ \\
\hline Medulla & 13 & $51.8 \pm 2.55$ & $1.33 \pm 0.06$ \\
\hline \multicolumn{4}{|l|}{ Dog } \\
\hline Cortex & 1 & 73.8 & 1.25 \\
\hline Medulla & 1 & 247.7 & 0.95 \\
\hline
\end{tabular}

four times the activity of "proximal" tubules. This suggests that a high Na-K-ATPase activity is a general property of distal as opposed to proximal segments of the nephron.

These speculations are supported by the elegant observations of Schmidt and Dubach (16), who assayed the activity of Na-K-ATPase in single segments of rat kidney tubules microdissected from frozen sections $16 \mu$ thick. Enzymatic activity was 4-8 times as high in segments of the ascending limb of the loop of Henle and the distal convolution as in the convoluted and straight portion of the proximal tubule; the activity in glomeruli was comparable to that in proximal tubules.

The high concentration of Na-K-ATPase in the distal nephron and especially in the thick ascending limb invites speculation about the reason for its presence. It is interesting, for example, that sodium reabsorption in the distal tubule is related (though in an irregular and nonstoichiometric way (28) to the movement of potassium in the opposite direction. Martinez-Maldonado, Allen, Eknoyan, Suki, and Schwartz (24) suggested

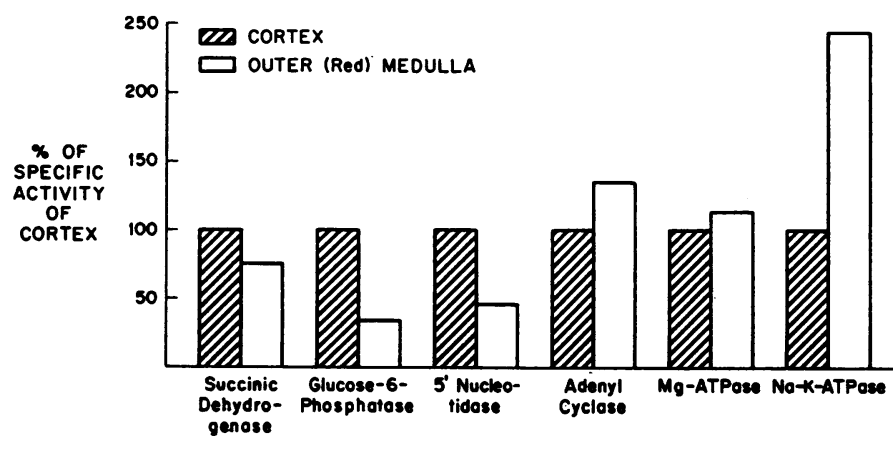

FiguRe 6 Distribution of enzymes in rat kidney. The crosshatched bars represent the specific activity in the cortex expressed as $100 \%$. The open bars represent the specific activity in red (outer) medulla expressed as a percentage of that in the cortex. Results shown are from determinations made in the $2200 \mathrm{~g}$ fraction for adenyl cyclase, in total microsomes for glucose-6-phosphatase and in whole homogenates for all the other enzymes. 
that the reason for high medullary ATPase might be related to the concentration of sodium achieved in the tubular fluid which is lower in the distal tubule than in the proximal; i.e., a stronger pump would be needed to reduce sodium concentration to $30-40 \mathrm{mEq} /$ liter in the distal tubule than to $140 \mathrm{mEq} /$ liter in the proximal tubule. It seems likely, however, that the difference in sodium concentration between distal and proximal tubules is related to a difference in permeability to water and sodium rather than to the mechanism of active transport. Sodium is presumably pumped from the interior of the cell across the periluminal border (29), and the concentration of sodium within distal tubular cells is probably close to that in proximal tubular cells $(30,31)$. The concentration gradient against which sodium must be transported is therefore similar in cells of the proximal and distal cortical convolutions, though external sodium tends to be higher in the medulla of the kidney than in the cortex, at least during hydropenia (32).

Another explanation has to do with the amount of sodium actively transported per unit of tissue by the ascending limb and the proximal convolution. The thick ascending limb of the rat is about one-half the length and one-half the width of the proximal convoluted tubule (33) ; its mass is therefore one-eighth as great. Nevertheless, its capacity for sodium reabsorption is relatively enormous. Studies of $\mathrm{T}^{\mathbf{c}}{ }_{\mathrm{H} \approx \mathrm{O}}$ excretion in saline-loaded rats indicate that the sodium transport system in the ascending limb of the loop of Henle is unsaturable up to the highest rate of sodium delivery to the loop of Henle that can be achieved in the intact animal (34). Cortney, Mylle, Lassiter, and Gottschalk (35) calculated from micropuncture studies that during hydropenia the proximal convolution of the rat nephron reabsorbed approximately three times as much sodium as the loop of Henle; the reabsorptive load per mass of tissue would therefore be roughly $8 / 3$ as much in the loop as in the proximal convolution. During an infusion of isotonic saline, however, about $42 \%$ of the glomerular filtrate was reabsorbed in the proximal convolution and approximately the same amount in the loop. In similar experiments of Landwehr, Klose, and Giebisch in rats infused with large quantities of Ringer's solution (36) an even larger proportion of the reabsorptive load was borne by the loop of Henle: $30 \%$ of the filtered load was reabsorbed in the proximal convolution and $56 \%$ in the loop. Under these circumstances the reabsorptive load per unit of tissue in the thick ascending limb would be some 8-16 times that in the proximal tubule, and this might require a localized high concentration of the "transport A TPase."

Finally, it is possible that sodium is transported by renal tubular cells in at least two different ways, one dependent on Na-K-ATPase and the other independent of it, and Whittembury has adduced evidence from experiments with tissue slices in support of this concept $(37,38)$. The present results would then suggest the hypothesis that the Na-K-ATPase-dependent or ouabain sensitive pathway predominates in the ascending limb and distal tubules, while a ouabain-insensitive pathway is prominent in the proximal tubule.

\section{ACKNOWLEDGMENTS}

The authors wish to thank Mrs. Nadia Myketey, Mrs. Truus Klein-Robbenhaar, and Mrs. Adele Powell for valuable technical assistance.

\section{REFERENCES}

1. Katz, A. I., and F. H. Epstein. 1968. Physiologic role of sodium-potassium-activated adenosine triphosphatase in the transport of cations across biologic membranes. N. Engl. J. Med. 278: 253.

2. Skou, J. C. 1965. Enzymatic basis for active transport of $\mathrm{Na}+$ and $\mathrm{K}+$ across cell membranes. Physiol. Rev. 45: 596.

3. Katz, A. I., and F. H. Epstein. 1967. The role of sodiumpotassium-activated adenosine triphosphatase in the reabsorption of sodium by the kidney. J. Clin. Invest. 46: 1999.

4. Fiske, C. H., and Y. Subbarow. 1925. The colorimetric determination of phosphorus. J. Biol. Chem. 66: 375.

5. Lowry, O. H., N. J. Rosebrough, A. L. Farr, and R. J. Randall. 1951. Protein measurement with the Folin phenol reagent. J. Biol. Chem. 193: 265.

6. Bonner, W. D. 1955. Succinic dehydrogenase. In Methods in Enzymology. S. P. Colowick and N. O. Kaplan, editors. Academic Press Inc., New York. 1: 722.

7. Michell, R. H., and J. N. Hawthorne. 1965. The site of diphosphoinositide synthesis in rat liver. Biochem. Biophys. Res. Commun. 21 : 333.

8. Krishna, G., B. Weiss, and B. B. Brodie. 1968. A simple, sensitive method for the assay of adenyl cyclase. J. Pharmacol. Exp. Ther. 163: 379.

9. Chase, L. R., and G. D. Aurbach. 1968. Renal adenyl cyclase: Anatomically separate sites for parathyroid hormone and vasopressin. Science (Washington). 159: 545.

10. Bray, G. A. 1960. A simple efficient liquid scintillator for counting aqueous solutions in a liquid scintillation counter. Anal. Biochem. 1: 279.

11. Matsui, H., and A. Schwartz. 1968. Mechanism of cardiac glycoside inhibition of the $\left(\mathrm{Na}^{+}-\mathrm{K}^{+}\right)$-dependent ATPase from cardiac tissue. Biochim. Biophys. Acta. $151: 655$.

12. Bonting, S. L., K. A. Simon, and N. M. Hawkins. 1961. Studies on sodium-potassium-activated adenosine triphosphatase. I. Quantitative distribution in several tissues of the cat. Arch. Brochem. Biophys. 95: 416.

13. Beyth, Y., and Y. Gutman. 1969. Ontogenesis of microsomal ATPase in the rabbit kidney. Biochim. Biophys. Acta. 191: 195.

14. Kriz, W. 1967. Der architektonische und functionelie Aufbau der Rattenniere. Z. Zellforsch. Mikrosk. Anat. 82: 495.

15. Rapp, J. P. 1967. Disassociation of J G granularity and blood pressure in adrenal regeneration. Amer. J. Physiol. 213: 947. 
16. Schmidt, U., and U. C. Dubach. 1969. Activity of $\left(\mathrm{Na}^{+}-\right.$ $\mathrm{K}^{+}$)-stimulated adenosintriphosphatase in the rat nephron. Pfluegers Arch. 306: 219.

17. Sullivan, W. J. 1968. Electrical potential differences across distal renal tubules of Amphiuma. Amer. J. Physiol. 214: 1096.

18. Emmelot, P., C. J. Boss, E. L. Benedetti, and Ph. Rümke. 1964. Studies on plasma membranes. I. Chemical composition and enzyme content of plasma membranes isolated from rat liver. Biochim. Biophys. Acta. 90: 126

19. Sutherland, E. W., G. A. Robison, and R. W. Butcher. 1968. Some aspects of the biological role of adenosine 3',5'-monophosphate (Cyclic AMP). Circulation. 37: 279.

20. Bonting, S. L., L. L. Caravaggio, and N. M. Hawkins. 1962. Studies on sodium-potassium-activated adenosinetriphosphatase. IV Correlation with cation transport sensitive to cardiac glycosides. Arch. Biochem. Biophys. 98: 413.

21. Bonting, S. L. 1963. Na-K Activated ATPase and active cation transport. In Water and electrolyte metabolism II. Elsevier, N. V. Vitgevers Mij., Amsterdam, (1964). 35.

22. Chignell, C. F., P. M. Roddy, and E. O. Titus. 1965. Effect of adrenal steroids on a $\mathrm{Na}^{+} \mathrm{K}^{+}$dependent adenosine triphosphatase. Life Sci. 4: 559.

23. Paul, W., and H. C. Gonick. 1968. Response of rat kidney $\mathrm{Na}^{+}-\mathrm{K}^{+}$-activated adenosine triphosphatase to sodium deprivation. Proc. Soc. Exp. Biol. Med. 127: 1175.

24. Martinez-Maldonado, M., J. C. Allen, G. Eknoyan, W. Suki, and A. Schwartz. 1969. Renal concentrating mechanism: Possible role for sodium-potassium activated adenosine triphosphatase. Science (Washington). 165: 807.

25. Jørgensen, P. L. 1969. Regulation of the $\left(\mathrm{Na}^{+}-\mathrm{K}^{+}\right)-$ activated ATP hydrolyzing enzyme system in rat kidney. II The effect of aldosterone on the activity in kidneys of adrenalectomized rats. Biochim. Biophys. Acta. 192: 326 .
26. Latta, H., A. B. Maunsbach, and L. Osvaldo. 1967. The fine structure of renal tubules in cortex and medulla in Ultrastructure of the kidney. A. J. Dalton and F. Haguenau, editors. Academic Press Inc., New York. 1.

27. Osvaldo, L., and H. Latta. 1966. The thin limbs of the loop of Henle. J. Ultrastruct. Res. 15: 144.

28. Malnic, G., R. M. Klose, and G. Giebisch. 1966. Micropuncture study of distal tubular potassium and sodium transport in rat nephron. Amer. J. Physiol. 211: 529.

29. Windhager, E. E. and G. Giebisch. 1965. Electrophysiology of the nephron. Physiol. Rev. 45: 214.

30. Whittembury, G., N. Sugino, and A. K. Solomon. 1961. Ionic permeability and electrical potential differences in Necturus kidney cells. J. Gen. Physiol. 44: 689.

31. Giebisch, G., G. Malnic, R. M. Klose, and E. E. Windhager. 1966. Effect of ionic substitutions on distal potential differences in rat kidney. Amer. J. Physiol. 211: 560.

32. Ullrich, K. J., K. Kramer, and J. W. Boylan. 1961. Present knowledge of the counter-current system in the mammalian kidney. Progr. Cardiovasc. Dis. 3: 395.

33. Sperber, I. 1944. Studies on the mammalian kidney. Zool. Bidr. Uppsala. 22 : 249.

34. Buckalew, V. M., Jr., M. A. Ramirez, and M. Goldberg. 1967. Free water reabsorption during solute diuresis in normal and potassium-depleted rats. Amer. J. Physiol. 212: 381 .

35. Cortney, M. A., M. Mylle, W. E. Lassiter, and C. W. Gottschalk. 1965. Renal tubular transport of water, solute, and $\mathrm{PAH}$ in rats loaded with isotonic saline. Amer. J. Physiol. 209: 1199.

36. Landwehr, D. M., R. M. Kose, and G. Giebisch. 1967. Renal tubular sodium and water reabsorption in the isotonic sodium chloride-loaded rat. Amer. J. Physiol. 212: 1327.

37. Whittembury, G. 1968. Sodium and water transport in kidney proximal tubular cells. J. Gen. Physiol. 51: 303 .

38. Whittembury, G. and Proverbio, F. 1970. Two modes of $\mathrm{Na}$ extrusion in cells from guinea pig kidney cortex slices. Pflüegers Arch. 316: 1. 